
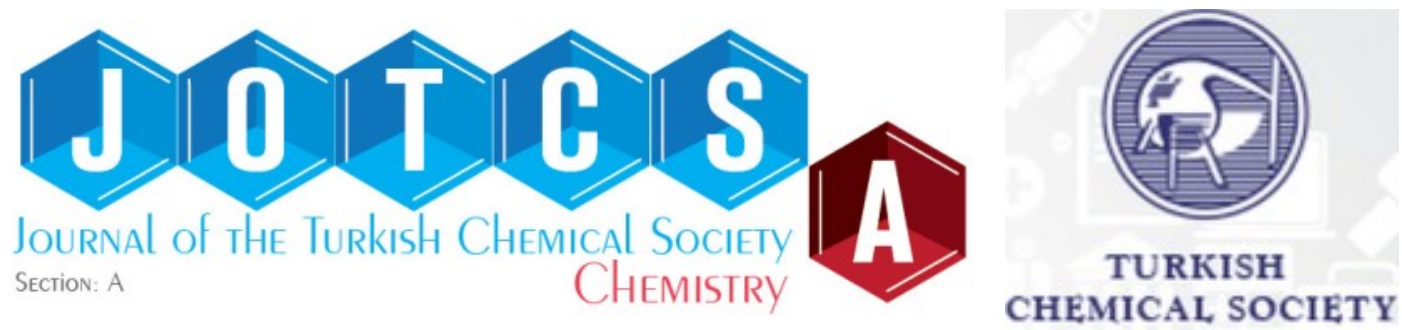

\title{
Assessment of Elemental Content, Antioxidant Activity, and Total Phenolic Content of Vitis sylvestris Gmelin
}

\author{
Nagihan Karaaslan Ayhan ${ }^{1,2} \square$ (D) \\ ${ }^{1}$ Munzur University, Tunceli Vocational School, Department of Chemistry and Chemical Processing \\ Technologies, Tunceli, Turkey. \\ ${ }^{2}$ Munzur University, Rare Earth Elements Application and Research Center, Tunceli, Turkey.
}

\begin{abstract}
In this study, we determined the $\mathrm{Cu}, \mathrm{Fe}, \mathrm{Mn}$, and $\mathrm{Zn}$ contents of Vitis sylvestris Gmelin using flame atomic absorption spectrometry (FAAS), and examined the antioxidant properties of Vitis sylvestris Gmelin using radical scavenging capacities and total phenolic content tests. We found the average elemental contents; $\mathrm{Cu}, \mathrm{Fe}, \mathrm{Mn}$, and $\mathrm{Zn}$ as $1.506 \pm 0.042 \mathrm{mg} / \mathrm{kg}, 0.796 \pm 0.020 \mathrm{mg} / \mathrm{kg}$, $2.333 \pm 0.033 \mathrm{mg} / \mathrm{kg}$, and $3.191 \pm 0.262 \mathrm{mg} / \mathrm{kg}$, respectively. When we examined the antioxidant activity tests applied to different extracts, we determined the highest extraction yield with the methanol extract. DPPH radical scavenging activity, ABTS radical scavenging activity, and total phenolic content values in methanol extract were determined to be respectively $3.957 \pm 0.146 \mathrm{mg}$ TEAC/g fw, $9.062 \pm 0.273 \mathrm{mg} \mathrm{TEAC} / \mathrm{g} \mathrm{fw}$, and $2.365 \pm 0.028 \mathrm{mg} \mathrm{GAE} / \mathrm{g} \mathrm{fw}$. When we evaluated the antioxidant activity and total phenolic content results for all extracts statistically, we determined that there was generally a statistically significant difference between each extract $(p<0.01)$. Vitis sylvestris Gmelin has high antioxidant content when considering the data obtained. Also, we determined that it is an effective candidate in the protection against reactive oxygen species.
\end{abstract}

Keywords: Vitis sylvestris Gmelin, elemental content, antioxidant activity, extraction.

Submitted: February 15, 2020. Accepted: April 07, 2020.

Cite this: Karaaslan Ayhan N. Assessment of Elemental Content, Antioxidant Activity, and Total Phenolic Content of Vitis sylvestris Gmelin. JOTCSA. 2020;7(2):405-10.

DOI: https://doi.org/10.18596/jotcsa.689329.

*Corresponding author. E-mail: nkaraaslan@munzur.edu.tr. Tel: +90 4282131794.

\section{INTRODUCTION}

Copper $(\mathrm{Cu})$, iron (Fe), manganese $(\mathrm{Mn})$, and zinc $(\mathrm{Zn})$ are essential elements for human health and should be taken into the body to maintain many important metabolic activities in the human body $(1,2)$. These elements play an essential role in the growth, development, and health of the human body (2-5). We can find $\mathrm{Cu}$ in the structure of many enzymes; similarly, $\mathrm{Zn}$ is defined as a cofactor in some enzymes and is involved in various metabolic activities. For example, if we do not take copper and zinc into the human body in sufficient quantities, then the bodily functions may be adversely affected. Consuming various vegetables, fruits, and food products supply the essential elements needed by the human body.

Antioxidants protect our body against diseases by reacting with almost all classes of compounds in the structure of living organisms, by taking a role in the reduction of reactive oxygen species (ROS), which cause significant damage. Antioxidant compounds have an essential role against diseases such as cancer, diabetes, gastrointestinal diseases, neurodegenerative diseases, and aging caused by excessive reactive oxygen species. Many synthetic antioxidant compounds are available, but it is clear that these compounds have toxic and mutagenic effects. In recent years, we started to prefer 
natural antioxidant compounds rather than synthetic ones, and we can take these compounds from various sources, including vegetables and fruits. Fruits and vegetables are rich antioxidant sources concerning phenolic compounds, anthocyanins, vitamins, and mineral elements in the literature $(6,7)$. Authors state that the adverse effects of free radicals reduce by consuming foods, including antioxidants, because of their positive effects on health $(6,8-10)$.

Turkey, a country rich in fruit and vegetable varieties, is a potential source of phenolic compounds, and one of them is wild grapes and grape varieties $(11,12)$. In the literature, there are studies about antioxidant activity, phenolic, vitamin, and elemental content of wild grapes grown in different regions (13-16). As a result of biodiversity, which is emerging due to physical geography characteristics, climate differences, and abundant water resources, it is determined that there is no data about wild edible Vitis sylvestris Gmelin reported (17) to naturally grown in PertekTunceli district (Turkey). In this context, we investigated the element content, antioxidant activity, and total phenolic content of Vitis sylvestris Gmelin.

\section{MATERIAL AND METHOD}

\section{Reagents and standards}

All chemicals and solvents used in sample and standard solution preparation were of analytically pure grade and obtained from Sigma-Aldrich and Merck. We used ultrapure water (Milli-Q, Millipore $18.2 \mu \Omega \mathrm{cm}-1$ ) in the experimental studies. We drew calibration graphs by standard solutions prepared in different concentration levels and used these graphs to evaluate the obtained data.

Element contents were determined using Perkin Elmer AAnalyst 800 flame atomic absorption spectrometer (FAAS) (Perkin Elmer, Inc., Shelton, CT, USA). The operation conditions are as follows: We set the wavelength and slit width for $\mathrm{Cu}$, Fe, $\mathrm{Mn}, \mathrm{Zn}$ respectively 324.8-07 nm, 248.3-0.2 nm, 279.5-0.2 nm, 213.9-0.7 nm, and acetylene and air flow rate was $2.0 \mathrm{~L} / \mathrm{min}$ and $17.0 \mathrm{~L} / \mathrm{min}$. We used a Shimadzu 1800 UV-Vis spectrophotometer for antioxidant activity measurements.

\section{Sample preparation}

Vitis sylvestris Gmelin (wild grape) naturally grown in Pertek-Tunceli, Turkey was gathered manually on the season, and then samples were mixed, washed with tap water, lastly passed through deionized water. We then stored them in the freezer until the analysis time.

Wet Digestion procedure for elemental analyses: We separated Vitis sylvestris Gmelin samples into small pieces, transferred approximately a $1-\mathrm{g}$ sample into the beakers, and dissolved with $2 \mathrm{~mL}$ of concentrated 1:1 HNO3: $\mathrm{H} 2 \mathrm{O} 2$ mixture. We evaporated the samples near dryness with occasional stirring and repeated the same procedure once again. We completed the final volumes to $5 \mathrm{~mL}$ with $1.0 \mathrm{M} \mathrm{HNO} 3$ and centrifuged to obtain homogeneous solutions. We carried out elemental analyses in the solutions using FAAS. Blank samples and standard reference materials $(0.25 \mathrm{~g})$ (NIST-1547 peach leaves) were also prepared using the same procedure and analyzed. We expressed the results as mean values \pm standard deviation of three independent analyses based on fresh weight.

Extraction procedure for antioxidant activity: We separated Vitis sylvestris Gmelin samples into small pieces, approximately $5 \mathrm{~g}$ samples transferred into the beakers, and acidified $10 \mathrm{~mL}$ of extraction solvents such as water, acetonitrile, and methanol with $0.1 \% \mathrm{HCl}$ to the samples. We then mixed the samples with extraction solvents for 60 min at room temperature and then centrifuged (10 $\min$ at $5000 \mathrm{rpm})$. We passed the clear solutions through a $0.45 \mu \mathrm{m}$ injection filter. For DPPH and ABTS radical scavenging activities, we applied total phenolic content tests to different sample extracts. We expressed the results as mean values \pm standard deviation of three independent analyses based on fresh weight.

\section{Antioxidant Activity Tests}

DPPH radical scavenging activities in the extracts were determined using the method applied by Brand-Williams et al. (18). We made the volumes of extracts taken in a certain amount to $2.5 \mathrm{~mL}$ with DPPH solution and then incubated for $30 \mathrm{~min}$ at room temperature. We used a UV-Vis spectrophotometer for the absorbance measurements of the solutions at $517 \mathrm{~nm}$. Trolox was the standard and stated the results as Troloxequivalent on fresh weight (mg TEAC/g fw).

We used the method proposed by Re et al. (19) to measure ABTS radical scavenging activity of the sample extracts. The extracts were made up to 2.5 $\mathrm{mL}$ with ABTS solution and incubated at room temperature for 30 minutes in the dark. At the end of the incubation time, we measured the absorbance values with a UV-Vis spectrophotometer at $734 \mathrm{~nm}$. Trolox was the standard, and we stated the results as Trolox equivalent on fresh weight (mg TEAC/g fw).

\section{Determination of Total Phenolic Content}

We determined the total phenolic contents by measuring the absorbance value of the color formed by adding the Folin-Ciocalteu reactant and $2 \%$ sodium carbonate solution to the extracts (20). We determined the absorbance values by 
measuring with a UV-Vis spectrophotometer at 755 $\mathrm{nm}$ after 30 minutes of incubation at room temperature. The standard was gallic acid and we expressed the experimental data in terms of gallic acid equivalent on fresh weight ( $\mathrm{mg} \mathrm{GAE} / \mathrm{g} \mathrm{fw}$ ).

We used GraphPad Software (version 5.01 for Windows, GraphPad Software, USA) for the statistical analyses for antioxidant activity and total phenolic content. We established the significance between the groups using the one-way analysis of variance (ANOVA) and Tukey's multiple comparison tests. We considered the differences statistically significant when $\mathrm{p}<0.01$.

\section{RESULTS AND DISCUSSION}

We used FAAS to determine $\mathrm{Cu}, \mathrm{Fe}, \mathrm{Mn}$, and $\mathrm{Zn}$ contents in Vitis sylvestris Gmelin. We found the $\mathrm{Cu}, \mathrm{Fe}, \mathrm{Mn}$, and $\mathrm{Zn}$ contents were $1.506 \pm 0.042$ $\mathrm{mg} / \mathrm{kg}, 0.796 \pm 0.020 \mathrm{mg} / \mathrm{kg}, 2.333 \pm 0.033$ $\mathrm{mg} / \mathrm{kg}$, and $3.191 \pm 0.262 \mathrm{mg} / \mathrm{kg}$, respectively. We tested the accuracy of the method with standard reference material (NIST-1547 peach leaves). We determined the certified values for this standard reference material to be $3.75 \pm 0.37 \mathrm{mg} /$ $\mathrm{kg}$ for $\mathrm{Cu}, 219.8 \pm 6.8 \mathrm{mg} / \mathrm{kg}$ for $\mathrm{Fe}, 97.8 \pm 1.8$ $\mathrm{mg} / \mathrm{kg}$ for $\mathrm{Mn}$, and $17.94 \pm 0.53 \mathrm{mg} / \mathrm{kg}$ for $\mathrm{Zn}$. In the present study, we found the $\mathrm{Cu}, \mathrm{Fe}, \mathrm{Mn}$, and $\mathrm{Zn}$ contents obtained with the used method to be $3.48 \pm 0.25 \mathrm{mg} / \mathrm{kg}, 198.7 \pm 7.0 \mathrm{mg} / \mathrm{kg}, 90.1 \pm$ $2.1 \mathrm{mg} / \mathrm{kg}$, and $17.08 \pm 0.48 \mathrm{mg} / \mathrm{kg}$, respectively. We found the recovery values for these elements to be $93 \%$ for $\mathrm{Cu}, 90 \%$ for $\mathrm{Fe}, 92 \%$ for $\mathrm{Mn}$, and $95 \%$ for $\mathrm{Zn}$.

A literature study has reported that $\mathrm{Cu}, \mathrm{Fe}, \mathrm{Mn}$, and $\mathrm{Zn}$ concentrations in grapes found from $0.4 \pm 0.1$ to $2.4 \pm 0.1 \mu \mathrm{g} / \mathrm{g}, 6.6 \pm 0.1$ to $14.8 \pm 0.3$ $\mu \mathrm{g} / \mathrm{g}, 3.1 \pm 0.2$ to $41.8 \pm 0.2 \mu \mathrm{g} / \mathrm{g}$, and $2.1 \pm 0.1$ to $20.4 \pm 1.0 \mu \mathrm{g} / \mathrm{g}$ in a study, respectively (21). In another study, researchers determined the element contents in the grape as $2.6 \pm 0.1 \mu \mathrm{g} / \mathrm{g}$ for $\mathrm{Cu}$, $3.8 \pm 0.2 \mu \mathrm{g} / \mathrm{g}$ for $\mathrm{Fe}, 3.4 \pm 0.2 \mu \mathrm{g} / \mathrm{g}$ for $\mathrm{Mn}$, and $2.2 \pm 0.1 \mu \mathrm{g} / \mathrm{g}$ for $\mathrm{Zn}$ (22). Researchers examined the elemental contents of some fruits and vegetables in a study. They found $\mathrm{Cu}$ and $\mathrm{Zn}$ concentrations in the grape to be $3.5 \mathrm{mg} / \mathrm{kg}$ and $6.1 \mathrm{mg} / \mathrm{kg}$, respectively (23). In the present study, the data concerning elemental contents were compatible, found with the literature data.
We determined the antioxidant activity of Vitis sylvestris Gmelin using DPPH and ABTS radical scavenging activities and total phenolic content tests, applying these tests to the extracts of the samples processed with water, acetonitrile and methanol, and evaluated the results statistically. There is a mention in a literature report that antioxidant activity results changed significantly depending on the solvent type (24-27). In the current study, we applied the antioxidant activity and total phenolic content test applied to different extracts; we obtained the highest results for all tests with methanolic extracts. As seen in Figure 1, average DPPH radical scavenging activity results were determined to be $0.537 \pm 0.060 \mathrm{mg} \mathrm{TEAC} / \mathrm{g}$ $\mathrm{fw}$ for aqueous extracts, $3.785 \pm 0.077 \mathrm{mg}$ TEAC/g $\mathrm{fw}$ for acetonitrile extracts, $3.570 \pm 0.08 \mathrm{mg}$ $\mathrm{TEAC} / \mathrm{g}$ fw for ethanolic extracts, and $3.957 \pm$ $0.146 \mathrm{mg} \mathrm{TEAC} / \mathrm{g}$ fw for methanolic extracts. We evaluated the results statistically. We found out that there were statistically significant differences between acetonitrile, ethanolic and methanolic extracts of aqueous extracts, and also between ethanolic and methanolic extracts. On the other hand, we determined that there were no statistically significant differences between ethanol and methanol extracts of acetonitrile extracts ( $p<$ 0.01).

We found the average ABTS radical scavenging activity results for water, acetonitrile, ethanol, and methanol extracts as $2.285 \pm 0.120 \mathrm{mg} \mathrm{TEAC} / \mathrm{g}$ $\mathrm{fw}, 7.984 \pm 0.355 \mathrm{mg} \mathrm{TEAC} / \mathrm{g} \mathrm{fw}, 8.471 \pm 0.642$ $\mathrm{mg} \mathrm{TEAC} / \mathrm{g} \mathrm{fw}$, and $9.062 \pm 0.273 \mathrm{mg} \mathrm{TEAC} / \mathrm{g} \mathrm{fw}$, respectively (Figure 2 ). When we examined the data statistically, we determined that there were statistically significant differences between acetonitrile, ethanolic, and methanolic extracts against aqueous extracts, and also between acetonitrile and methanolic extracts. On the other hand, we found that there were no statistically significant differences between acetonitrile and methanol extracts of ethanol extracts ( $p<0.01)$. While we found the highest total phenolic content in methanolic extracts $(2.365 \pm 0.028 \mathrm{mg} \mathrm{GAE} / \mathrm{g}$ $\mathrm{fw})$, the lowest total phenolic content was in aqueous extracts $(0.592 \pm 0.045 \mathrm{mg} \mathrm{GAE} / \mathrm{g} \mathrm{fw})$ (Figure 3). When we statistically compared the data for total phenolic contents, we found that there was a statistically significant difference between every two extracts except for acetonitrile and ethanolic extracts ( $p<0.01)$. 


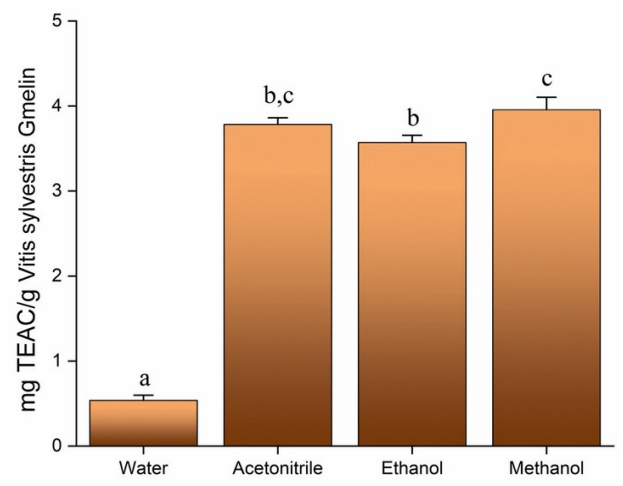

Figure 1: DPPH radical scavenging activity of Vitis sylvestris Gmelin.

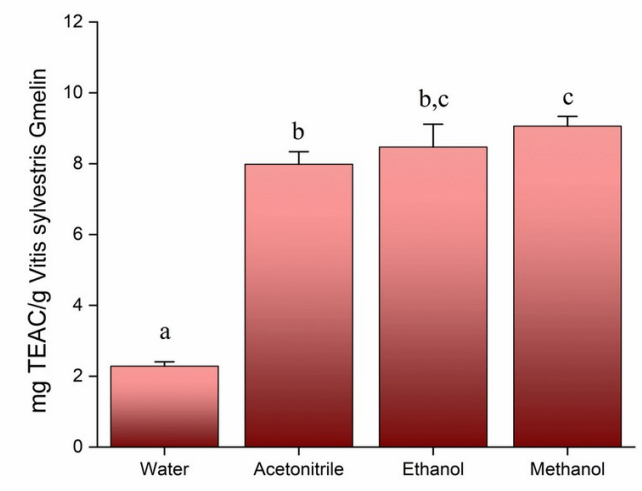

Figure 2: ABTS radical scavenging activity of Vitis sylvestris Gmelin.

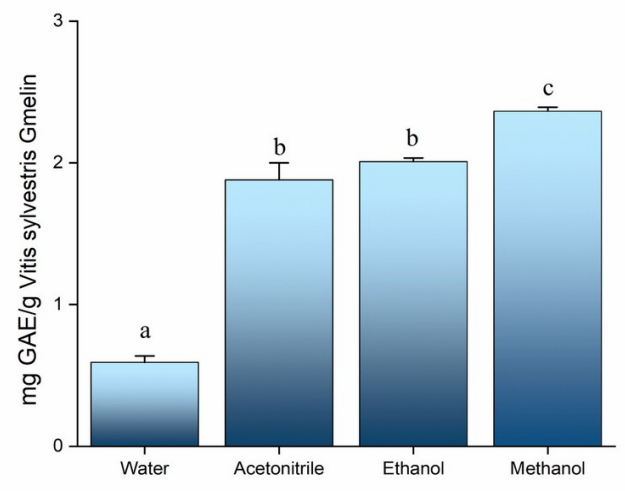

Figure 3: Total phenolic content of Vitis sylvestris Gmelin.

In a study, researchers examined phenolic profile and antioxidant activity of different grape varieties and reported total phenolic content results in a range from $0.44 \pm 0.02$ to $7.94 \pm 0.19 \mathrm{mg}$ gallic acid equivalents/g grape sample (28). Antioxidant activity of black grape obtained applying different drying methods determined with DPPH and ABTS assay, total phenolic content tests. Literature reports that antioxidant activity results changed depending on different drying methods. The highest value for total phenolic content found to be $20.21 \mathrm{mg} / \mathrm{g}$ DW in fresh grapes, but this value in the freeze-, oven- and sun-dried samples continued to decrease. The values of DPPH and ABTS antioxidant activities in fresh grapes determined as $66.07 \mathrm{mmol}$ TE/ $\mathrm{kg}$ DW and 137.65 $\mathrm{mmol} \mathrm{TE} / \mathrm{kg}$ DW (29). Total phenolic compounds of red grape varieties examined by Correia and 
Jordão found to be average $1341.0 \mathrm{mg} / \mathrm{L}$, and antioxidant capacities determined varying from 3.96 to $32.96 \mathrm{~mm} / \mathrm{L} \mathrm{Fe}$ (II) (30). The results in the presented study were compatible with those found in the literature. Researchers determined that the data changed importantly depending on different conditions such as drying method, extraction method, and solvent type, as stated in the literature $(24-27,30)$.

\section{CONCLUSIONS}

In this study, we investigated the elemental content and antioxidant activity of Vitis sylvestris Gmelin. Elemental analysis results carried out as applied to the wet digestion method were determined to be $1.506 \pm 0.042 \mathrm{mg} / \mathrm{kg}$ for $\mathrm{Cu}$, $0.796 \pm 0.020 \mathrm{mg} / \mathrm{kg}$ for Fe, $2.333 \pm 0.033 \mathrm{mg} / \mathrm{kg}$ for $\mathrm{Mn}$, and $3.191 \pm 0.262 \mathrm{mg} / \mathrm{kg}$ for $\mathrm{Zn}$, respectively. We have found that DPPH and ABTS radical scavenging activity, total phenolic content results tested with different polar solvents are $3.957 \pm 0.146 \mathrm{mg} \mathrm{TEAC} / \mathrm{g} \mathrm{fw}, 9.062 \pm 0.273 \mathrm{mg}$ TEAC/g fw, $2.365 \pm 0.028 \mathrm{mg} \mathrm{GAE} / \mathrm{g} \mathrm{fw}$ for methanol extracts determined as the best solvents. Vitis sylvestris Gmelin naturally grown in Pertek, Tunceli; according to the obtained results can be evaluated as an antioxidant food, especially, we will add new data with this study about the fruit to the literature.

\section{CONFLICT OF INTEREST}

The author declares no conflict of interest.

\section{REFERENCES}

1. Martínez-Ballesta MC, Dominguez-Perles R, Moreno DA, Muries B, Alcaraz-López C, Bastías E, et al. Minerals in plant food: effect of agricultural practices and role in human health. A review. Agron Sustain Dev. 2010 Apr;30(2):295-309.

2. Yin $Y$, Li $Y$, Li Q, Jia N, Liu $A$, Tan $Z$, et al. Evaluation of the Relationship Between Height and Zinc, Copper, Iron, Calcium, and Magnesium Levels in Healthy Young Children in Beijing, China. Biol Trace Elem Res. 2017 Apr;176(2):244-50.

3. Salgueiro MJ, Zubillaga MB, Lysionek AE, Caro $R A$, Weill R, Boccio JR. The role of zinc in the growth and development of children. Nutrition. 2002 Jun; 18(6):510-9.

4. Đermanović M, Miletić I, Pavlović Z. A Comparative Analysis of the Contents Of Iron, Zinc, Copper, Manganese, and Calcium in the Collective Diet Of Preschool Children in the Northwestern Region of Bosnia. Biol Trace Elem Res. 2017 Jan;175(1):27-32.
5. Cao J, Gao Z, Yan J, Li M, Su J, Xu J, et al. Evaluation of Trace Elements and Their Relationship with Growth and Development of Young Children. Biol Trace Elem Res. 2016 Jun;171(2):270-4.

6. Manach C, Scalbert A, Morand C, Rémésy C, Jiménez L. Polyphenols: food sources and bioavailability. The American Journal of Clinical Nutrition. 2004 May 1;79(5):727-47.

7. Hanasaki Y, Ogawa S, Fukui S. The correlation between active oxygens scavenging and antioxidative effects of flavonoids. Free Radical Biology and Medicine. 1994 Jun;16(6):845-50.

8. Robards K, Antolovich M. Analytical Chemistry of Fruit BioflavonoidsA Review. Analyst. 1997;122(2):11R-34R.

9. Zhu F. Anthocyanins in cereals: Composition and health effects. Food Research International. 2018 Jul;109:232-49.

10. M. Calderon-Montano J, Burgos-Moron E, Perez-Guerrero C, Lopez-Lazaro M. A Review on the Dietary Flavonoid Kaempferol. MRMC. 2011 Apr $1 ; 11(4): 298-344$.

11. Karataş DD, Karataş H, Laucou V, Sarikamiş G, Riahi L, Bacilieri R, et al. Genetic diversity of wild and cultivated grapevine accessions from southeast Turkey. Hereditas. 2014 Oct;151(45):73-80.

12. Ergül A, Perez-Rivera G, Söylemezoğlu G, Kazan K, Arroyo-Garcia R. Genetic diversity in Anatolian wild grapes ( Vitis vinifera subsp. sylvestris ) estimated by SSR markers. Plant Genet Res. 2011 Aug;9(3):375-83.

13. Dastoor R, Bakhshi D, Aliakbar A. Resveratrol and other phenolic compounds from wild grape Vitis vinifera. ssp sylvestris. JBES. 2017;11(4):121-30.

14. Jiménez $M$, Juárez $N$, Jiménez-Fernández $V M$, Monribot-Villanueva JL, Guerrero-Analco JA. Phenolic compounds and antioxidant activity of wild grape (vitis tiliifolia). Italian Journal of Food Science [Internet]. 2017 Nov 21 [cited 2020 Apr 7];30(1). Available from: http://doi.org/10.14674/ IJFS-975

15. Margaryan K, Melyan G, Vardanyan D, Devejyan $\mathrm{H}$, Aroutiounian R. Phenolic content and antioxidant activity of Armenian cultivated and wild grapes. Aurand J-M, editor. BIO Web Conf. 2017;9:02029. 
16. Revilla E, Bellido A, Yus J, Ortiz P, Carrasco D, Arroyo RA. Flavonols in skins of wild grapes ( Vitis vinifera L., subsp. sylvestris (Gmelin) Hegi). Aurand J-M, editor. BIO Web Conf. 2016;7:01018.

17. Doğan A. Pertek (Tunceli) yöresinde etnobotanik araştırmalar [PhD Thesis]. [İstanbul]: Marmara University; 2014.

18. Brand-Williams W, Cuvelier M, Berset C. Use of a Free Radical Method to Evaluate Antioxidant Activity. Lebensm-Wiss u-Technol. 1995;28:25-30.

19. Re R, Pellegrini N, Proteggente A, Pannala A, Yang $M$, Rice-Evans $C$. Antioxidant activity applying an improved ABTS radical cation decolorization assay. Free Radical Biology and Medicine. 1999 May;26(9-10):1231-7.

20. Singleton V, Rossi J. Colorimetry of Total Phenolics with Phosphomolybdic-Phosphotungstic Acid Reagents. American Journal of Enology and Viticulture. 1965;16:144-58.

21. Unsal Y, Yilmaz E, Soylak M, Tuzen M. Trace element contents of raisins, grape and soil samples from Incesu-Kayseri, Turkey. Fresenius Environmental Bulletin. 2013;22(5):1441-5.

22. Yami SG, Chandravanshi BS, Wondimu T, Abuye $C$. Assessment of selected nutrients and toxic metals in fruits, soils and irrigation waters of Awara Melka and Nura Era farms, Ethiopia. SpringerPlus. 2016 Dec;5(1):747.

23. Aydinalp C, Marinova S. Concentration of $\mathrm{Cu}$ and $\mathrm{Zn}$ in Some fruits and Vegetables grown in north western Turkey. Bulgarian Journal of Agricultural Science. 2012;18(5):749-51.

24. Mitic M, Kostic D, Pavlovic A, Dimitrijevic D, Veljkovic J. Effects of solvent extraction system on concentration and antioxidant activity of strawberry phenolics. Agro Food Industry Hi-Tech. $2014 ; 25(5): 24-8$.

25. Boulekbache-Makhlouf L, Medouni L, MedouniAdrar S, Arkoub L, Madani K. Effect of solvents extraction on phenolic content and antioxidant activity of the byproduct of eggplant. Industrial Crops and Products. 2013 Aug;49:668-74.

26. Karaaslan MG, Karaaslan NM, Ates B. Investigation of Mineral Components and Antioxidant Properties of a Healthy Red Fruit: Cornelian Cherry (Cornus mas L.). Journal of the Turkish Chemical Society, Section A: Chemistry. 2018 Nov 17;1319-26.

27. Karaaslan NM, Karaaslan MG, Ates B. Effects of Some Extraction Solvents on the Antioxidant Properties of Strawberry Fruit. International Journal of Pure and Applied Sciences [Internet]. 2018 Dec 27 [cited 2020 Apr 7]; Available from: http://dergipark.gov.tr/doi/10.29132/ijpas.354885

28. Di Lorenzo C, Colombo F, Biella S, Orgiu F, Frigerio G, Regazzoni L, et al. Phenolic profile and antioxidant activity of different grape ( Vitis vinifera L.) varieties. Aurand J-M, editor. BIO Web Conf. 2019;12:04005.

29. Çoklar H, Akbulut M. Effect of sun, oven and freeze-drying on anthocyanins, phenolic compounds and antioxidant activity of black grape (Ekşikara)(Vitis vinifera L.). South African Journal of Enology and Viticulture. 2017;38(2):264-272.

30. Correia AC, Jordão AM. Antioxidant capacity, radical scavenger activity, lipid oxidation protection analysis and antimicrobial activity of red grape extracts from different varieties cultivated in Portugal. Natural Product Research. 2015 Mar $4 ; 29(5): 438-40$. 